\title{
Modification of the system of screening for antisyphilis antibodies in a blood transfusion centre, featuring a miniaturisation of the Treponema pallidum haemagglutination assay
}

\author{
A PUCKETT, G PRATT \\ From the Regional Transfusion Centre, John Radcliffe Hospital, Headington, Oxford OX3 9DU
}

SUMMARY A modified, miniaturised version of the Fujizoki Treponema pallidum haemagglutination assay (TPHA) is described. The method is fast, sensitive, specific, and very economical.

During a test period of one year, use of the method gave rise to a $67 \%$ increase in confirmed positives among new donor sera and a $112.5 \%$ increase among the antenatal sera over the numbers that would have been detected using a cardiolipin test alone.

With the new donor sera, the rate of confirmed positives detected during the test period was $150 \%$ greater than that of 1980 , when a cardiolipin test alone was used $\left(0 \cdot 05>p>0 \cdot 02\left(X^{2}\right.\right.$ test $\left.)\right)$.

For many years, the only test employed in this centre for screening donor blood for antibodies to syphilis has been the VDRL flocculation test and latterly the VDRL carbon antigen test performed by the manual method. It had been suspected that these tests were not detecting all those donations which contained syphilis antibodies. During 1978, 14 VDRL positives were detected out of a total of 113153 donations. Five of these $(0.004 \%)$ were confirmed by the Venereal Disease Reference Laboratory at Whitechapel. During 1979, the laboratory staff were instructed to scrutinise the tests more critically and refer all positive reactions, however minimal or weak. Twenty-nine VDRL positives were reported in 1979 out of 108310 donations. Eleven of these $(0.01 \%)$ were confirmed as cases of syphilis. In 1980, 13 VDRL positives were found out of 116757 donors of which seven were confirmed $(0 \cdot 007 \%)$. Of these donors, 20670 were new donors. In this group there were seven VDRL positives of which four were confirmed $(0.02 \%)$.

Manual testing has been preferred to automated testing because of its greater sensitivity. This is underlined by Barbara et al ${ }^{1}$ who in 35500 samples found two confirmed positives by automated VDRL testing, but nine confirmed positives by manual testing. In the same period he found 39 confirmed

Accepted for publication 2 June 1982 positives using a modified TPHA, using $0 \cdot 1 \%$ cells in microtitre plates.

Although the $0.1 \%$ TPHA modification by Barbara et al is relatively inexpensive, it still costs considerably more than the carbon antigen test.

The miniaturisation of haemagglutination tests in Terasaki plates has been successfully demonstrated by Wiseman in his modification of reverse passive haemagglutination for hepatitis B antigens. ${ }^{2}$ Therefore it was decided to miniaturise the TPHA test using Terasaki plates (from Becton Dickenson, Grenoble, France), in an effort to reduce the cost still further.

Simultaneously, a parallel trial was undertaken using Rapid Plasma Reagin (RPR-Becton Dickenson Ltd) and the Venereal Disease Reference Laboratory test (VDRL-Tissue Culture Services Ltd).

\section{Material and methods}

Fujizoki TPHA 100 test kits are supplied by Diamed Diagnostics Ltd (Bootle, Merseyside). The Oxford miniaturisation requires extra diluent obtained from the same company.

\section{SERUM DILUTION}

In the standard Fujizoki microtitre test, the final 
dilutions of serum including the addition of cell suspension are $1 / 80$ and $1 / 160$.

In the Oxford miniaturisation, sera are screened at the single dilution of $1 / 16(1 / 24$ including cell suspension). This dilution is made in two stages using a Compupet (General Diagnostics, Eastleigh, Hants). Firstly, 1/8 dilution is dispensed into the well of a Tendix WHO plate (Appleton-Woods, Birmingham) from which $10 \mu \mathrm{l}$ of a further $1 / 2$ dilution are dispensed into the well of a Terasaki plate.

\section{CELL DILUTIONS}

In the standard Fujizoki method, the test cells are primarily reconstituted with $0.8 \mathrm{ml}$ of distilled water making a concentration of $2.5 \%$. This is further diluted $1 / 6.5$ by the addition of $4.4 \mathrm{ml}$ of absorbing buffer, then $75 \mu \mathrm{l}$ of this suspension are added to $25 \mu \mathrm{l}$ of diluted serum in the test.

In the Oxford miniaturisation, $5 \mu$ of cell suspension are added to $10 \mu$ l diluted serum.

We have calculated that for the same final concentration of cells in serum, the suspension yielded by the primary reconstitution can be used.

\section{FURTHER CELL DILUTION FOR ECONOMY}

Determination of minimum cell concentration: a known positive serum was titrated and the dilutions tested by the Fujizoki technique and the Oxford miniaturisation.

In the latter method cells were tested in a range of dilutions to determine the maximum dilution showing no drop in sensitivity. This was $1 / 5$. Thus, the cells are reconstituted with $0.8 \mathrm{ml}$ distilled water (primary reconstitution), then $3.2 \mathrm{ml}$ absorbing diluent are added (1/5 dilution). Control cells are reconstituted with $0.5 \mathrm{ml}$ distilled water and diluted with $2.0 \mathrm{ml}$ absorbing diluent.

\section{PERFORMANCE OF TEST}

Serum dilutions are prepared and left in the Terasaki plates on the bench for at least $30 \mathrm{~min}$, for absorption of non-specific antibodies by the diluent.

Then, $5 \mu$ l of cell suspension are added to each $10 \mu \mathrm{l}$ serum dilution using a Hamilton Multidispenser (VA Howe \& Co Ltd), giving a final dilution of 1/24. A known positive serum is titrated and set up with the test and control cells.

The plates are sloped at an angle of $30^{\circ}$ from the horizontal and left at room temperature for at least $2 \mathrm{~h}$. The haemagglutination patterns are examined over a diffused light source.

In a negative test the cells settle in a discrete crescent-shaped button. In a positive test a fine carpet of cells is seen.

All sera showing any reactivity are titrated in the range $1 / 16$ to $1 / 256$ and retested using test and control cells.

Sera reactive by test and control cells are absorbed by making a $1 / 16$ dilution of serum in control cells. This is left at $4^{\circ} \mathrm{C}$ overnight, centrifuged and then titrated again with test and control cells.

\section{PERFORMANCE OF CARDIOLIPIN TESTS}

The carbon antigen reagents for the VDRL and RPR tests were supplied by Tissue Culture Services Ltd (Slough, Berks) and Becton Dickenson U.K. Ltd (Wembley, Middlesex) respectively.

The manual technique as performed at this centre is the same for both tests. Serum $(0.05 \mathrm{ml})$ is pipetted onto the well of a glass slide. Cardiolipin carbon antigen $(0.02 \mathrm{ml})$ is added with a dropping pipette. Forty samples plus a positive control are tested on each slide, which is then rotated at $100 \mathrm{rpm}$ for $8 \mathrm{~min}$. The tests are read against a white background under a strong white light. Samples showing any degree of agglutination are titrated and retested.

\section{SCHEME OF PRESENT WORK}

1 The Oxford miniaturisation was performed on panel No 190 of control sera for syphilis supplied by the Division of Microbiological Reagents and Quality Control of the Public Health Laboratory Service. This was done in parallel with the standard Fujizoki TPHA, the VDRL test and the RPR test.

2 In the period 30 January 1981 to 30 September 1981 , the Oxford miniaturisation, the VDRL and the RPR test were performed on 26036 sera, comprising 15020 antenatal sera and 11016 new donor sera.

Sera positive by either TPHA or a cardiolipin test, or both, were sent to the Bacteriology Laboratory at Northampton General Hospital for testing by the Absorbed Fluorescent Treponemal Antibody Test (FTA (ABS)), which was regarded as the final indicator of probable syphilitic infection.

3 During period 1 October 1981 to 29 January 1982, the Oxford miniaturisation and the RPR test were performed on a further 19227 samples of serum, comprising 11019 antenatal sera and 8208 new donor sera.

This results in a total for the period 28 January 1981 to 29 January 1982 of 45253 sera comprising 26029 antenatal sera and 19224 new donor sera.

\section{Results}

PHLS QUALITY CONTROL SERA

Table 1 shows the comparative titres of the standard Fujizoki TPHA with the Oxford miniaturisation and the VDRL test with the RPR test. The Oxford miniaturisation performs well in comparison with the standard Fujizoki TPHA, in which the titres of 
Table 1 Results of VDRL, RPR and miniaturised TPHA tests on PHLS Quality Control Sera Panel No 190

\begin{tabular}{|c|c|c|c|c|c|c|}
\hline \multirow[t]{2}{*}{ Serum } & \multirow[t]{2}{*}{$V D R L$} & \multirow{2}{*}{$\begin{array}{l}\text { RPR } \\
\text { titre }\end{array}$} & \multirow{2}{*}{$\begin{array}{l}\text { Oxford } \\
\text { TPHA titre }\end{array}$} & \multirow{2}{*}{$\begin{array}{l}\text { Fujizoki } \\
\text { TPHA titre }\end{array}$} & \multicolumn{2}{|c|}{ PHLS expected results } \\
\hline & & & & & $V D R L$ & TPHA \\
\hline $\begin{array}{l}600 \\
601 \\
602 \\
603 \\
604 \\
605\end{array}$ & $\begin{array}{l}1 / 4 \\
\text { neg } \\
1 / 8 \\
1 / 4 \\
1 / 1 \\
\text { neg }\end{array}$ & $\begin{array}{l}1 / 8 \\
\text { neg } \\
1 / 32 \\
1 / 8 \\
1 / 2 \\
1 / 2\end{array}$ & $\begin{array}{l}1 / 512 \\
\text { neg } \\
1 / 1024 \\
1 / 512 \\
\text { neg } \\
1 / 512\end{array}$ & $\begin{array}{l}1 / 1280 \\
\text { neg } \\
1 / 2560 \\
1 / 640 \\
\text { neg } \\
1 / 1280\end{array}$ & $\begin{array}{l}1 / 8-1 / 16 \\
\text { neg } \\
1 / 32 \\
1 / 8-1 / 16 \\
\text { neg-1/2 } \\
1 / 1\end{array}$ & $\begin{array}{l}1 / 1280-1 / 2560 \\
\text { neg } \\
1 / 2560-1 / 5120 \\
1 / 1280-1 / 2560 \\
\text { neg } \\
1 / 1280-1 / 2560\end{array}$ \\
\hline
\end{tabular}

positive sera are generally one doubling dilution higher.

The RPR titres are one doubling dilution greater than the VDRL titres except for serum 605, which was VDRL-negative and RPR 1/2.

ANALYSIS OF CARDIOLIPIN TESTS IN THE PERIOD 28 JANUARY 1981 TO 30 SEPTEMBER 1981

In this period 26036 sera were tested by TPHA, RPR and VDRL.

Eleven sera were positive by all three tests, all but one of these were FTA(ABS)-positive, and this one had a TPHA titre of only $1 / 32$.

One serum was TPHA, RPR and FTA(ABS)positive, but VDRL-negative. There were no sera that were TPHA and FTA(ABS)-positive but RPR-negative.

Seventeen sera were TPHA-negative and either VDRL- or RPR- or both positive. All of these sera were FTA(ABS)-negative. At this stage, VDRL testing was discontinued.

CARDIOLIPIN AND TPHA TESTING IN THE PERIOD 28 JANUARY 1981 TO 29 JANUARY 1982

Table 2 shows the results of testing 45253 antenatal and new donor sera.

Thirty-one TPHA positives were found of which 28 were confirmed by FTA(ABS). Three were falsepositive $(10 \%)$, but none of these had a titre greater than 1/32. Forty-four cardiolipin positives were found of which 16 were confirmed by FTA(ABS). Twentyeight were false-positive (64\%).

There were no sera that were cardiolipin-positive, TPHA-negative and FTA(ABS)-positive.

Table 2 Sera showing positive results in 45223 antenatal and new donor samples

\begin{tabular}{llll}
\hline & Total & $\begin{array}{l}F T A(A B S)- \\
\text { positive }\end{array}$ & $\begin{array}{l}\text { FTA(ABS)- } \\
\text { negative }\end{array}$ \\
\hline $\begin{array}{l}\text { TPHA-positive } \\
\text { Cardiolipin-positive }\end{array}$ & 16 & 15 & $1^{*}$ \\
$\begin{array}{l}\text { TPHA-positive } \\
\text { Cardiolipin-negative }\end{array}$ & 15 & 13 & $2^{*}$ \\
$\begin{array}{l}\text { TPHA-negative } \\
\text { Cardiolipin-positive }\end{array}$ & 28 & 0 & 28 \\
\hline
\end{tabular}

* None of these sera had a TPHA titre greater than $1 / 32$.
An overall $87 \%$ increase in detection of positives is shown when TPHA is used.

Of the 45253 sera, 26026 were antenatal samples and 19224 were new donor samples.

The increase in detection of positives when TPHA is used is $112.5 \%$ with antenatal sera, and $67 \%$ with new donor sera.

Of 19224 new donor sera, there were 10 confirmed positives found $(0.05 \%)$. In 1980 , when TPHA was not used there were 20670 new donor sera out of which there were four confirmed positives $(0.02 \%)$. This represents a $150 \%$ increase in positive sera from 1980 to the test period. This increase is significant $\left(0.05>p>0.02\left(X^{2}\right.\right.$ test $\left.)\right)$.

\section{Discussion}

These results show the Oxford miniaturisation of the Fujizoki TPHA to be rapid, sensitive, specific, very economical and suited to routine screening. The very slight reduction in sensitivity is more than compensated for by the fact that screening is done at a final dilution of $1 / 24$ in the Oxford miniaturisation as opposed to $1 / 80$ in the Fujizoki technique.

The choice of a cut-off titre in our system was difficult. Since no TPHA positive sample at a serum dilution of less than $1 / 32$ was confirmed by FTA(ABS), 1/32 was chosen as the cut-off titre. Even at this dilution, the majority of TPHA positives were FTA(ABS)-negative.

A strong positive can carry-over by two or three wells. In this case, all the sera showing positive reactions are retested. Carry-over can be obviated by expelling a volume of diluent between each dilution into a suitable container and wiping the dispenser tip with a paper tissue. However, the system is bestsuited to the testing of large numbers of specimens and we found better economy of labour by retesting the samples involved.

There is no reason why the system should not be easily reproducible in other laboratories, and be economical of both labour and materials when it is used for mass screening.

The greater sensitivity of RPR over VDRL was demonstrated both by the improved titres in Table 1 
and by the sample shown in Table 2 that was RPR, TPHA- and FTA(ABS)-positive and VDRLnegative.

The results shown in Table 2 demonstrate that many samples containing syphilis antibodies are missed by using only a cardiolipin test in screening (87\% increase). It is likely, though, that many of the TPHA-positive, cardiolipin-negative sera are from treated cases of syphilis that are no longer infectious. This was indicated by those patient/donor histories to which we had access. However, they might also be late, latent or congenital syphilis. ${ }^{34}$

Since the TPHA method was described by Rathlev in $1967,{ }^{5}$ it has been recognised as being generally more sensitive than cardiolipin tests, but there is controversy as to their relative sensitivities in early primary syphilis. According to Jaffé et al, ${ }^{6}$ Lesinski et $a l,{ }^{7}$ Young et $a l^{8}$ and Sequeira and Eldridge, ${ }^{4}$ cardiolipin tests are more sensitive than TPHA in early primary syphilis, although TPHA is more sensitive at all other stages of the disease. All these authors also comment on the high specificity of the TPHA and Young et al state that the test has the characteristics of both a screening test and a verification test. Further evidence of the very high specificity of the TPHA is provided by Garner et $a l^{9}$ and Johnston. ${ }^{10}$

Case histories of syphilis in which the TPHA was the first test to become positive are recorded by Jephcott et al ${ }^{11}$ and Wright and Gerkin. ${ }^{12}$ Wright and Gerkin also suggested that TPHA could be used as a screening test and cardiolipin tests dispensed with altogether. Luger $e^{t}$ al $^{13}$ and Dyckman et al ${ }^{14}$ are of the opinion that TPHA is consistently reactive before cardiolipin tests even in early primary syphilis.

Our findings do not resolve this controversy, although they do indicate that many more positive samples would be found using TPHA alone, than would by using a cardiolipin test alone. They also demonstrate that the combination of a cardiolipin test and TPHA is a very good screening system, as previously shown by Simon and Peacock. ${ }^{15}$

The greater increase in positives found by Barbara et al, (333\% as compared with our $87 \%)$, may be a reflection of geographical area rather than sensitivity of testing.

Present evidence indicates that neither TPHA nor cardiolipin tests should be relied upon alone in screening.

The RPR and miniaturised TPHA used in combination are highly specific and give excellent sensitivity at all stages of the disease. Both tests can be performed on a single sample for less than a penny (reagent costs), giving the transfusion centre greater confidence in its donor blood and, perhaps more importantly, providing useful information for clinicians in the antenatal field.

We would like to record our thanks to the Director of this Centre, Dr CC Entwistle for his help and encouragement, the Area Venereologist, Dr JMD Galway for useful advice and Dr Severn and the staff of the Northampton Bacteriology Laboratory for performing the FTA(ABS) tests.

\section{References}

' Barbara JAJ, Salker R, Fatima L, Davies TD, Harris JB. An economical, simplified haemagglutination test for mass syphilis screening. J Clin Pathol 1980;33:1216-8.

${ }^{2}$ Wiseman IC. A modification of Hepatest, using the Terasaki plate, for the detection of HBsAg in blood donors. J Clin Pathol 1976;29:264-6.

${ }^{3}$ Luger A, Spendlingwimmer J. Appraisal of the Treponema pallidum haemagglutination test. BrJ Vener Dis 1973;49:181-2.

${ }^{4}$ Sequeira PJL, Eldridge AE. Treponemal haemagglutination test. Br J Vener Dis 1973;49:242-8.

${ }^{5}$ Rathlev Tara. Haemagglutination test utilising pathogenic Treponema pallidum for the serodiagnosis of syphilis. $\mathrm{Br} J$ Vener Dis 1967;43:181-5.

- Jaffé Harold W, Larsen Sandra A, Jones BS, Dans Peter E. Haemagglutination tests for syphilis antibody. Am J Clin Patho 1978;70(2):230-3.

${ }^{7}$ Lesinski J, Krach J, Kadziewicz E. Specificity, sensitivity and diagnostic value of the TPHA test. Br J Vener Dis 1974;50:33440.

${ }^{8}$ Young H, Henrichsen C, Robertson DHH. Treponema pallidum haemagglutination test as a screening procedure for the diagnosis of syphilis. BrJ Vener Dis 1974;50:341-6.

${ }^{9}$ Garner MF, Blackhouse JL, Daskalopoulos G, Walsh JL. Treponema pallidum haemagglutination test for syphilis. Comparison with the TPI and FTA-ABS tests. BrJ Vener Dis 1972;48:470-3.

${ }^{10}$ Johnston NA. Treponema pallidum haemagglutination tests for syphilis. Evaluation of a modified micromethod. BrJ Vener Dis 1972;48:474-8.

"Jephcott AE, Beveridge MAM, Sequeira PJL. Early TPHA response in primary syphilis. Br J Vener Dis 1977;53:147.

${ }^{12}$ Wright DJM, Gerken A. Antenatal screening for syphilis. $\mathrm{Br} \mathrm{J}$ Vener Dis 1981;57:147-8.

${ }^{13}$ Luger A, Schmidt B, Spendlingwimmer I, Horn F. Recent observations on the serology of syphilis. Br J Vener Dis 1980;56:12-16.

${ }^{14}$ Dyckman JD, Storms S, Huber TW. Reactivity of microhaemagglutination, fluorescent treponemal antibody absorption, and venereal disease research laboratory tests in primary syphilis. J Clin Microbiol 1980;12,4:629-30.

is Simon RD, Peacock AM. Comparison between the automated reagin test and reagin screen methods of VDRL screening tests for syphilis in use in a routine laboratory. J Clin Pathol 1977;30:626-9.

Requests for reprints to: Mr A Puckett, The Regional Transfusion Centre, John Radcliffe Hospital, Headington, Oxford OX3 9DU, England. 